\title{
Study of polyaromatic hydrocarbons in current used motor oils
}

\begin{abstract}
Used motor oils (UMO) are hazardous wastes due particularly to the content of polyaromatic hydro-carbons (PAH) which accumulate in UMO primarily as result of incomplete combustion of fuel. Thus, UMO constitute exceptionally harmful contaminants polluting the environment. This statement had full validity in the latter half of the past century, authentically reflecting an issue that actually had existed at that time. However, the progress in the field has substantially increased the quality of UMO so that it is now possible to consider whether the current UMO are or are not hazardous wastes. In this article, two methodologies were used for PAH evaluation, the IP 346 method with permitted value of the main cancerogene benzo(a)pyrene (b(a)p) $0.005 \%$. and the methodology based on ${ }^{1} \mathrm{H}$ NMR spectroscopy, where the proportion of bay hydrogens (Hbay) must not exceed $0.35 \%$ of all the hydrogens present, respectively. 32 UMO samples were tested for PAH content and it was stated that every sample was well below the permitted limits. Also, heavy metal content in selected samples shows the levels order of magnitude lower than the maximum permitted values. This creates the possibility of energy utilization of UMO at the place of their obtaining without unnecessary legislation measures.
\end{abstract}

Keywords: used motor oil, polyaromatic hydrocarbons, IP 346, 'H NMR spectroscopy, heavy metals, hazardous wastes
Volume 2 Issue 7 - 2017

\author{
Ján Cvengroš, Tibor Liptaj, Nad’a Prónayová \\ Faculty of Chemical and Food Technology, Slovak Technical \\ University, Slovakia
}

\begin{abstract}
Correspondence: Ján Cvengroš, Faculty of Chemical and Food Technology, Slovak Technical University, Slovakia, Tel 004212948
\end{abstract} 322 537, Email crejan0I@gmail.com

Received: August 15, 2017 | Published: September 06, 2017

\section{Introduction}

Used motor oils (UMO) are a remarkable commodity arousing interest of each new generation of researchers. UMO also include used gear oils, but their degree of use is much lower. The primary role of motor oil is to reduce friction and prevent corrosion. It also serves to dissipate heat and hold in suspension by-products of engine wear, combustion and degradation products. Motor oil originates from base oils obtained from petroleum fractions. Petroleum, however, contains only a small percentage (2-4\%) $)^{1}$ of components suitable for this purpose. The main base oil constituents are paraffins, olefins, aromates and cyclanes.

At the onset of motorism, motor oils were simple hydrocarbon systems free from any additives, with antioxidants being added later. As the development of engines progressed, the number of additives increased, providing for new parameters of lubricating oils (detergentdispersant, antioxidant, anticorrosion, viscosity-modifying, anti-wear, antifoam additives etc.). Such additives, 6 to 8 in number, are mixed with the base oil as a package (concentrated mixture of additives in mineral oil) in an amount of up to $20 \%$ by volume. While fresh motor oil containing the package is not a hazardous waste, UMO do constitute hazardous wastes. ${ }^{2}$ Fossil fuel combustion gives rise to polymeric systems- condensed aromatic hydrocarbons PAH (polycyclic aromatic hydrocarbons) that tend to occupy the surface of cylinders, pistons and piston rings, form hard films and scratch surfaces. The role of motor oils is to remove and wash away such products as well as restoring and maintaining the original condition. PAH are very dangerous to health because some are known to be mutagenic and carcinogenic. ${ }^{3}$ Oil loses its functional parameters especially through exhaustion of additives, chemical changes and concentrating of impurities. UMO impurities include decomposed additives, products of imperfect fuel combustion, abraded material etc. The PAH content in a new motor oil is relatively low ${ }^{2,4}$ but increases with motor operating time. ${ }^{2,5,6} \mathrm{UMO}$ can contain 670 times more PAH than new motor oils. ${ }^{7}$ The PAH content of UMO from petrol motors can be 180 times higher than that of new oil., ${ }^{4,9}$, The Benzo (a) pyrene content of new motor oil can be up to $0.266 \mathrm{mg} / \mathrm{kg}$ but that of UMO from petrol cars can be up to $216 \mathrm{mg} / \mathrm{kg}$, i.e. 1000 times higher. This is caused by accumulation of the PAH from fueled petrol and especially of the PAH formed during imperfect fuel combustion. UMO are hazardous wastes particularly due to PAH content. In the past, PCB was also involved but at present are not so relevant. Another hazardous UMO component is particulate matter (PM), originating from abrasion and additives. Particulate matter, however, can be eliminated. PAH thus remain a significant environmental contaminant. ${ }^{10-12}$

Mutagenic and carcinogenic effects of PAH and their adverse effects on the environment are stressed in a number of papers. ${ }^{13-16}$ Vazquez ${ }^{3}$ assesses UMO as very dangerous polluting products. As a consequence of its chemical composition, world-wide dispersion and effects on the environment, UMO must be considered a serious environmental problem. Considerable quantities of heavy metals such as $\mathrm{Pb}, \mathrm{Zn}, \mathrm{Cu}, \mathrm{Cr}, \mathrm{Ni}, \mathrm{Cd}$ are contained in $\mathrm{UMO}$; these metals are highly toxic to organisms. The author analyzes PAH production during the combustion engine operation and further fate of UMO in the environment. He describes their effects on soil and aquatic organisms, discusses UMO combustion focusing specifically on environmental impacts and assesses UMO biodegradability. According to van Donkelaar, ${ }^{17}$ too, UMO are extremely polluting products, having a serious impact on the environment. This highly dangerous material leaves the engine in various ways such as via particulates, oil leaks and uncontrolled oil changes and then tends to accumulate again in the environment. The paper of Hewstone ${ }^{18}$ indicates the health, safety and environmental aspects, which have been expressed regarding the handling, re-use and disposal of UMO. Accumulation of UMO in the environment leads to health problems resulting from mutagenic and carcinogenic compounds contained in UMO. ${ }^{2}$ However, a vast 
majority of such papers dates back to the latter half of the past century, authentically reflecting an issue that actually existed at that time.

Further development in the engine technology at the beginning of the $21^{\text {st }}$ century changed the situation dramatically. The progress in motor technology, particularly high-pressure fuel injection connected with high fuel atomization and lower PAH formation, new fuel injection technologies (common rail, unit injector), short motor oil change intervals, high quality of additives and base oils, and new suction techniques for UMO removal from the engine without the possibility of their being contaminated have substantially increased the quality of UMO so that it is now possible to consider whether the current UMO are or are not hazardous wastes with all the corollaries (organized collection, recording, storage, disposal).

There is a number of legislations that are currently used to categorize UMO as hazardous wastes. A standard procedure for the isolation and determination of the content of the PAH-containing fraction is described in the Institute of Petroleum standard IP $346^{20}$ which is widely used all over the world..$^{21,22}$ The procedure is based on the gravimetric determination of the fraction soluble in dimethyl sulphoxide (DMSO) at room temperature. The maximum allowed concentration of PAH is limited by the value of $3.0 \% \mathrm{w} / \mathrm{w}$. However, the procedure is not sufficiently selective for the analysis of trace amounts of PAH because the extract contains too much of other aromatic hydrocarbons. Another test in use is the determination of the content of benzo(a)pyrene (b(a)p) and seven additional PAHs (socalled car PAHs - see Table 1). According to the Regulation (EC) No. 1907/2006, Note M, the limit value required for a sample to be assessed as being harmful is the $b(a) p$ content of $0.005 \% \mathrm{w} / \mathrm{w}$, or the $\sum 8 \mathrm{PAH}$ content of $10.0 \mathrm{mg} / \mathrm{kg}$. In particular b(a)p has been identified as being highly carcinogenic. ${ }^{23,24}$ The US Environmental Protection Agency has declared 16 unsubstituted PAHs (EPA-PAHs) as priority pollutants ${ }^{25}$ Table 1 .

Table I Selected PAH structures (so-called car PAHs) as carcinogenicity carriers [19] and some of their parameters

\begin{tabular}{|c|c|c|c|c|c|c|}
\hline Chemical Name & Structural Formula & $\begin{array}{l}\text { CAS } \\
\text { Number }\end{array}$ & $\begin{array}{l}\text { Chemical } \\
\text { Formula }\end{array}$ & $\begin{array}{l}\text { Molecular } \\
\text { Weight, g.mol-1 }\end{array}$ & $\begin{array}{l}\text { Melting } \\
\text { Point, }{ }^{\circ} \mathrm{C}\end{array}$ & $\begin{array}{l}\text { Boiling } \\
\text { Point, }{ }^{\circ} \mathrm{C}\end{array}$ \\
\hline Benzo(a)pyrene & & $50-32-8$ & $\mathrm{C}_{20} \mathrm{H}_{12}$ & 252.3 & 176 & 495 \\
\hline Benzo(e)pyrene & & $192-97-2$ & $\mathrm{C}_{20} \mathrm{H}_{12}$ & 252.3 & 180 & 495 \\
\hline Benzo(a)anthracene & & $56-55-3$ & $\mathrm{C}_{18} \mathrm{H}_{12}$ & 228.3 & 158 & 438 \\
\hline $\begin{array}{l}\text { Benzo(a) } \\
\text { phenanthrene } \\
\text { (chrysene) }\end{array}$ & & $218-01-9$ & $\mathrm{C}_{18} \mathrm{H}_{12}$ & 228.3 & 253 & 448 \\
\hline Benzo(e)fluoranthene & & $205-99-2$ & $\mathrm{C}_{20} \mathrm{H}_{12}$ & 252.3 & $163-165$ & 481 \\
\hline Benzo(j)fluoranthene & & $205-82-3$ & $\mathrm{C}_{20} \mathrm{H}_{12}$ & 252.3 & 166 & 480 \\
\hline Benzo(k)fluoranthene & & $207-08-9$ & $\mathrm{C}_{20} \mathrm{H}_{12}$ & 252.3 & $215-217$ & 480 \\
\hline $\begin{array}{l}\text { Dibenz(a,h) } \\
\text { anthracene }\end{array}$ & & $53-70-3$ & $\mathrm{C}_{22} \mathrm{H}_{14}$ & 278.3 & $266-267$ & 524 \\
\hline
\end{tabular}


The Salmonella/microsome test -Ames test - is one of the most valid and widely used mutagenicity assays. ${ }^{26,27}$ It serves to determine carcinogenic and mutagenic potential of chemical compounds. The Ames test uses several strains of the bacterium Salmonella typhimurium that carry mutations in genes involved in histidine synthesis. These strains are auxotrophic mutants, i.e. they require histidine for growth. The method tests the capability of the tested substance in creating of reversion mutations so that the cells can grow on a histidine-free medium.

The carcinogenicity of PAHs has been shown to be related to the occurrence in the molecule of "bay regions" which are characterized as reactive sites having high double bond character. ${ }^{28}$ By using ${ }^{1} \mathrm{H}$ NMR spectroscopy it is possible to measure the proportion of hydrogen atoms located at bay regions in PAH molecules and so quantify the content of carcinogenic PAHs in the sample. According to Coker at al. ${ }^{28}$ the signals in the spectrum between 8.30 to 9.20 ppm belong to bay region protons. Coker has correlated animal test data with bay region protons measurement and found the threshold of carcinogenicity for base oils to be about $1000 \pm 400 \mathrm{ppm}$ of bay region protons. Di Serio et al. ${ }^{29}$ has tested some UMO regenerates over long period for the PAH content by means of the IP 346 method and evaluated their carcinogenicity by means of ${ }^{1} \mathrm{H}$ NMR spectroscopy. The results have shown that the total PAH content was always less than $3 \%$ and the content of carcinogenic PAH was much under the limit value set by Coker et al.. ${ }^{28}$ According to the Regulation (EC) No. 1907/2006 and EN ISO 21461:2012, UMO containing less than $0.35 \% \mathrm{w} / \mathrm{w}$ of Hbay-type hydrogens may be used as extender oils in rubber manufacturing.

UMO are not ecologically safe but their physical properties make it a suitable material for valuable reuse. The heat of UMO combustion is the same as the heat of combustion of petroleum derived fuels but is much less expensive. ${ }^{3} \mathrm{UMO}$ may be re-refined into base oils of quality comparable to virgin base oils. ${ }^{30}$ They can also be transformed into fuel to be used in incinerators for heat generation or in power plants to generate electricity. As regards UMO regeneration, supply currently exceeds demand, which is why energy utilization is also acceptable. ${ }^{31}$ In the EU, at present, about $50 \%$ of used oils are collected, of which approximately $87 \%$ are incinerated and $13 \%$ regenerated. ${ }^{1}$ In UMO, high levels of toxic heavy metals are accumulated, originating from both abrasion and additives. The heavy metals involved are particularly $\mathrm{Pb}, \mathrm{Zn}, \mathrm{Cu}, \mathrm{Cd}, \mathrm{As}, \mathrm{Cr}$ and others. Safe incineration takes place in cement kilns at temperatures around $1200^{\circ} \mathrm{C}$ and residence times of 4 s. ${ }^{1}$ Metals are captured in clinker. ${ }^{32}$ Small-scale incinerating facilities are subject to regulation ${ }^{1}$ and are equipped with gas-cleaning systems. However, most of the metals present remain in the ash residue. ${ }^{3}$ An important fact being stressed is that the ash residue generated from UMO burning should be managed in an environmentally protective manner. ${ }^{33}$

This paper purports to determine the PAH content in current UMO samples and to compare it to literature data from the end of the past century as well as comparing PAH values determined by IP 346 methodology with the results obtained by ${ }^{1} \mathrm{H}$ NMR spectroscopy using Hbay methodology. To determine, in the selected set of UMO samples, the content of heavy metals which are limited by regulatory limits.

\section{Experimental}

\section{Materials}

30 UMO samples were obtained from local sources (car repair shops, freight companies) in Slovakia and Austria as mixtures of motor and gear oils from petrol and diesel engines. Two UMO samples came from diesel generators of cogeneration plants. Samples were collected from storage tanks with oil volume of over 50 liters, usually from 200-liter barrels. In some cases storage tanks having a volume of over $1 \mathrm{~m}^{3}$ were used for sample collection. In collecting the samples, the principle of separate waste collection with no contamination by other oils and operating liquids was stressed. Samples thus represent average UMO from at least 5 and more vehicles. Samples were used for measurements without any further treatment. The reference sample of fresh motor oil was Madit Uniol SAE 15W-40, produced by Slovnaft, a.s., Bratislava, Slovakia.

\section{Methods}

The content of eight PAH monitored (see Table 1) was determined in 15 selected samples by accredited laboratories of ALS, Czech Republic, using a modified method according to IP 346 (ISO 11 338). ${ }^{34}$ In this procedure, the sample is extracted with DMSO and for the PAH determination proper, GC-HRMS is used. Isotope dilution method with deuterium-labeled PAH analogs as internal standards is utilized here. PAH determination is thus more accurate than the gravimetric determination of aromatics following their extraction with DMSO. Measurement uncertainty is double the relative standard deviation, corresponding to the expanded measurement uncertainty at a $95 \%$ confidence level. The estimate of relative uncertainty of determining the individual PAH is $30 \%$.

For NMR analyses, $0.5 \mathrm{ml}$ of $\mathrm{CDCl}_{3}$ was added to $0.5 \mathrm{ml}$ of the sample in its original condition, and the sample was placed in a 5 mm NMR tube. All NMR measurements were carried out on an Agilent (Varian) VNMRS $600 \mathrm{MHz}$ spectrometer at a ${ }^{1} \mathrm{H}$ operating frequency of $599.76 \mathrm{MHz}$. The measurements were conducted at $25^{\circ} \mathrm{C}$, using the basic pulse scheme for measuring ${ }^{1} \mathrm{H}$ spectra. The most important operating parameters were: $45^{\circ}$ excitation pulse ( $p w$ $=3.1 \mu \mathrm{s}$ ), relaxation interval $\mathrm{d} 1=2 \mathrm{~s}$; acquisition time $a t=1.7039$ s, spectral width: $14 \mathrm{ppm}-(-2) \mathrm{ppm}$, and number of scans $n s=256$. The measured data were processed in a standard manner (Fourier transform, phase shifting, baseline shifting, and integration). Data were evaluated independently 5 times. In NMR measurements all 32 samples were used together with the reference sample of fresh motor oil Madit.

The content of the limited heavy metals ( $\mathrm{As}, \mathrm{Cd}, \mathrm{Cr}, \mathrm{Pb}$ ) and nonlimited heavy metals $(\mathrm{Ba}, \mathrm{Ni}, \mathrm{Sb})$ was determined in three UMO samples (UMO 4, UMO 13 and UMO15), listed in Table 2. UMO samples for heavy metal content determination were digested with nitric acid and hydrogen peroxide, as specified in method 6010, US SW-846, 1986. The Inductively Coupled Plasma - Atomic Emmision Spectroscopy (ICP-AES) was used for analysis of total heavy metals in oil matrix (EN ISO 11885). The results are the average of three determinations. Flash points of the tested UMO samples were determined according EN ISO 2592: 2000.

\section{Results and discussion}

\section{PAH content in UMO samples according to modified IP 346}

Table 2 provides contents of 8 PAH monitored according to the Regulation (EC) No. 1907/2006 (so-called car PAHs) in 15 samples of the UMO set tested and their sums.

The limit for assessing PAH harmfulness is the b(a)p content of less than $0.005 \%$ w/w (Regulation (EC) No. 1907/2006, Note M), in 
which case the material need not be classified as carcinogenic. Another criterion for assessing PAH harmlessness, applicable to processing oils in rubber type manufacturing, is the $\mathrm{b}(\mathrm{a}) \mathrm{p}$ content below $1 \mathrm{mg} / \mathrm{kg}$ and $\sum 8 \mathrm{PAH}$ content under $10 \mathrm{mg} / \mathrm{kg}$.

Table 2 Content of selected PAH in UMO samples as determined by modified IP 346

\begin{tabular}{|c|c|c|c|c|c|c|c|c|c|}
\hline Sample & $\begin{array}{l}\text { Benzo } \\
\text { (a)Anth- } \\
\text { Racene }\end{array}$ & $\begin{array}{l}\text { Benzo } \\
\text { (a)Phen- } \\
\text { Anthrene }\end{array}$ & $\begin{array}{l}\text { Benzo } \\
\text { (b)Fluor- } \\
\text { Anthene }\end{array}$ & $\begin{array}{l}\text { Benzo } \\
\text { (k)Fluor-Anthene }\end{array}$ & $\begin{array}{l}\text { Benzo } \\
\text { (j)Fluor- } \\
\text { Anthene }\end{array}$ & $\begin{array}{l}\text { Benz (e) } \\
\text { Pyree }\end{array}$ & $\begin{array}{l}\text { Benzo } \\
\text { (a) } \\
\text { Pyree }\end{array}$ & $\begin{array}{l}\text { Dibenzo } \\
\text { (a,h)Anth- } \\
\text { Racene }\end{array}$ & $\Sigma 8 \mathrm{PAH}$ \\
\hline UMOI & $<0.15$ & $<0.31$ & $<0.18$ & $<0.18$ & $<0.17$ & $<0.33$ & $<0.13$ & $<0.13$ & 1.6 \\
\hline UMO2 & 14 & 9 & 3.8 & 3.2 & 3.2 & 7.8 & 7.7 & $<0.85$ & 49 \\
\hline UMO3 & 16 & 8.6 & 5.7 & 4.2 & 5.4 & 10 & 7.9 & $<0.85$ & 59 \\
\hline UMO4 & 7.8 & 5.7 & 3.9 & 2.5 & 3.5 & 5.4 & 5.6 & $<0.85$ & 35 \\
\hline UMO5 & 8.1 & 5.1 & 2.4 & 1.8 & 2.1 & 4.2 & 4.1 & $<0.85$ & 29 \\
\hline UMOI3 & 1.5 & 0.92 & 1.3 & 0.58 & 0.67 & 1.35 & 1.2 & 0.2 & 7.8 \\
\hline UMOI5 & 2.6 & 1.7 & 2.9 & 1.3 & 1.6 & 2.6 & 1.6 & 0.4 & 15 \\
\hline UMOI7 & 19 & 7.8 & 6.4 & 3.7 & 4.2 & 7.7 & 4.2 & 1.4 & 54 \\
\hline UMOI8 & 18 & 6.9 & 4.6 & 2.7 & 3.6 & 6.1 & 4.6 & I.I & 47 \\
\hline UMOI9 & 4.8 & 2.7 & 2.3 & I.I & 1.6 & 2.7 & 1.3 & 0.5 & 17 \\
\hline UMO24 & $<0.37$ & $<1.2$ & $<0.32$ & $<0.37$ & $<0.43$ & $<0.57$ & $<0.5$ I & $<0.22$ & 4 \\
\hline UMO25 & 5.6 & 3.4 & 1.8 & I.I & 1.5 & 2.3 & 2.6 & $0.4 I$ & 19 \\
\hline UMO26 & 9.5 & 7 & 2.2 & 1.5 & 2.2 & 3.2 & 6.1 & 0.47 & 32 \\
\hline UMO28 & $<0.53$ & $<1.2$ & $<0.43$ & $<0.5$ & $<0.58$ & $<0.76$ & $<0.64$ & $<0.33$ & 5 \\
\hline UMO29 & $<0.42$ & $<0.42$ & $<0.26$ & $<0.3$ & $<0.35$ & $<0.45$ & $<0.47$ & $<0.28$ & 3 \\
\hline
\end{tabular}

PAH content in $\mathrm{mg}^{. \mathrm{kg}^{-1}}$

The $\mathrm{b}(\mathrm{a}) \mathrm{p}$ content in the $15 \mathrm{UMO}$ samples tested, as provided in Table 2, indicates that the values for all 15 samples are well below the limit of $0.005 \% \mathrm{w} / \mathrm{w}(50 \mathrm{mg} / \mathrm{kg})$, which makes it unnecessary to classify the samples as carcinogens. The lowest value was found in sample UMO1, being about 380 times lower than the admissible value, while the highest value found in sample UMO3 (7.9) is about 6 times lower than the limit. Furthermore, 5 samples with $\sum 8$ PAH value below $10 \mathrm{mg} / \mathrm{kg}$ can be used as extender oils in rubber manufacturing technologies.

\section{PAH content in UMO determined by ' $H$ NMR spectroscopy}

Motor oils contain predominantly alkanes along with small amounts of aromatic and cyclanic structures. During their operation in the engine, they gradually accumulate decomposition products of additives as well as products from incomplete combustion and thermal decomposition of fuel molecules and their subsequent recombination particularly to PAH. Potential UMO toxicity is then related to UMO contamination by some PAH which are known as procarcinogens. PAH become carcinogenic after being transformed metabolically into diol epoxides, which attack DNA, giving rise to mutant cells. ${ }^{35}$ It was discovered that the greatest mutagenic potential of PAH is exhibited by structures that could give rise to the epoxide group located between aromatic rings, i.e. in the bay-shaped PAH structural fragment (socalled "bay region"). ${ }^{36-38}$ PAH with "bay region" structures are thus considered as markers of UMO carcinogenic toxicity, and the determination of such PAH's content as the manner of assessing the UMO toxicity level.
From the perspective of UMO toxicity determination, the NMR method is based on the fact that potentially carcinogenic PAH are typically manifested in the ${ }^{1} \mathrm{H}$ NMR spectrum by having the signal of their "bay" hydrogens located within a specific spectral region from 9.5 to $8.3 \mathrm{ppm}$ and well separated from the other signals. ${ }^{28,29}$ This is demonstrated in Figure 1 on simulated spectra of typical representatives of procarcinogenic PAH. The arrows on the structures mark the "bay" regions, and individual "bay" hydrogens are highlighted (in color). The corresponding signals in the spectra are marked in color. The spectral region containing "bay" proton signals (9.6-8.3 ppm) is marked with a blue frame Figure 1.

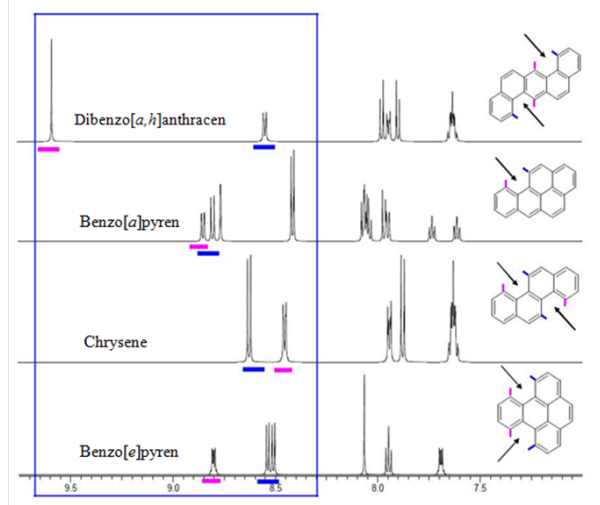

Figure I Simulated 'H NMR spectra of typical PAH representatives with carcinogenic effects. 
NMR is one of the most universal methods for qualitative as well as quantitative determination of organic substances. When compared to other analytical methods, it has several important advantages. Firstly, it is a non-invasive procedure that allows analyzing the sample in its original condition where no or little pre-treatment is needed (addition of a deuterated solvent). This largely eliminates potential distortion of results caused by the sample treatment procedure required by most analytical methods. Secondly, NMR provides undistorted information on the content of individual components in the sample. This is because NMR sensitivity is the same for all components in the mixture. An important advantage of NMR is that it provides an overall picture on the state of the sample, i.e. also information on the components that are not the subject of the analysis but that can reveal the overall nature of the sample Figure 2.

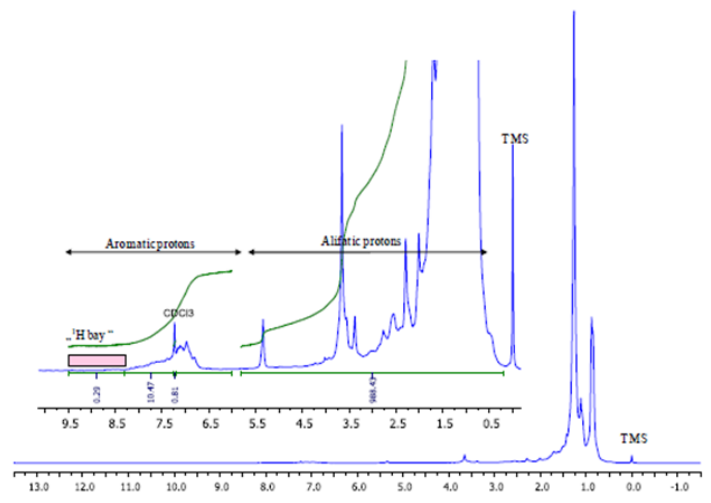

Figure 2 'H NMR spectrum of a typical UMO sample

Figure 2 presents a typical ${ }^{1} \mathrm{H}$ NMR spectrum for UMO. On a vertically expanded spectrum are marked resonance regions of various hydrogen types as well as their integral intensities used to calculate PAH content as a "bay" proton content. Dominant signals in the spectrum correspond to $n$-alkanes and cyclanic structures (region from $0.5 \mathrm{ppm}$ to $2.2 \mathrm{ppm}$ ). Minority components can also be seen in the vertically expanded spectral record. Signals detected in the region from 3 to $5.5 \mathrm{ppm}$ belong to oxidized saturated structures. Aromatic hydrogens resonate in the region from 6 to $9.5 \mathrm{ppm}$. Part of aromatic hydrogens from the "bay" region resonates between 8.3 and $9.5 \mathrm{ppm}$. Other peaks visible in the spectrum are the peak of the solvent, $\mathrm{CHCl}_{3}$, at $7.23 \mathrm{ppm}$, which contributes to integral intensity of aromatic hydrogens, and peak of the chemical shift reference standard, TMS (tetramethylsilane, $0 \mathrm{ppm}$ ).

In this paper, NMR determination of polycyclic aromatics content was carried out based on the comparison of the integral intensity corresponding to the "bay" proton signal, with the integral intensity of all protons in the sample, except for $\mathrm{CHCl}_{3}$ and TMS proton signals. We chose to follow the same procedure as outlined in the ISO document, ${ }^{30}$ which provides a method for the determination of polyaromaticity of oils suitable for rubber industry processing. Aromaticity/polyaromaticity is expressed here as a content of aromatic, or "bay" protons:

$$
\begin{aligned}
& \% \mathrm{H}_{\text {arom }}=100\left(I_{\text {arom }} / I_{\text {total }}\right) \\
& \% \mathrm{H}_{\text {bay }}=100\left(I_{\text {Hbay }} / I_{\text {total }}\right)
\end{aligned}
$$

Where $I_{\mathrm{xy}}$ designate integral intensities of signals as displayed in Figure 2:

$$
\begin{aligned}
& \quad I_{\text {alif }}=I_{0.2-6.0 \mathrm{ppm}}, I_{0}=I_{6.0-9.5 \mathrm{ppm}}, I_{\text {arom }}=I_{0}-I_{\mathrm{CHCl13}}, I_{\mathrm{Hbay}}=I_{8.3-9.5 \mathrm{ppm}}, I_{\text {total }}= \\
& I_{\text {alif }}+I_{\text {arom. }}
\end{aligned}
$$

The measured and processed integral signal intensities according

\begin{tabular}{|c|c|c|c|c|c|c|c|c|}
\hline \multirow[t]{3}{*}{ Sample } & \multirow[t]{2}{*}{$I_{0}$} & \multirow[t]{2}{*}{$I_{\mathrm{CHCl3}}$} & $I_{\text {arom }}$ & $I_{\text {Hbay }}$ & $I_{\text {alif }}$ & $I_{\text {total }}$ & $\% \mathbf{H}_{\text {bay }}$ & \multirow[t]{3}{*}{$\% \mathbf{H}_{\text {arom }}$} \\
\hline & & & \multicolumn{5}{|l|}{$=I_{0}-I_{\mathrm{CHCl3}}$} & \\
\hline & 9.5-6.0 ppm & $7.23 \mathrm{ppm}$ & 9.5-6.0 ppm & 9.5-8.3 ppm & 5.8-0.2 ppm & \multicolumn{2}{|c|}{ 9.5-0.2 ppm } & \\
\hline Madit & $13.8 \mid$ & 0.44 & 13.37 & 0.09 & 992.93 & 1006.3 & 0.009 & 1.33 \\
\hline UMOI & 6.74 & 0.94 & 5.8 & 0.07 & 995.21 & 1001.01 & 0.007 & 0.58 \\
\hline UMO2 & 10.58 & 0.63 & 9.95 & 0.31 & 992.35 & 1002.29 & 0.031 & 0.99 \\
\hline UMO3 & 10.1 & 1.11 & 8.99 & 0.26 & 996.07 & 1005.06 & 0.026 & 0.89 \\
\hline UMO4 & 10.39 & 1.15 & 9.24 & 0.28 & 992.94 & 1002.18 & 0.028 & 0.92 \\
\hline UMO5 & 25.69 & 0.94 & 24.76 & 0.2 & 991.53 & 1016.28 & 0.019 & 2.44 \\
\hline UMO6 & 10.35 & 0.67 & 9.68 & 0.28 & 988.97 & 998.64 & 0.028 & 0.97 \\
\hline UMO7 & 13.49 & 0.98 & 12.52 & 0.32 & 992.61 & 1005.12 & 0.032 & 1.25 \\
\hline UMO8 & 7.82 & 0.77 & 7.05 & 0.18 & 995.69 & 1002.74 & 0.018 & 0.7 \\
\hline UMO9 & 10.32 & 0.76 & 9.56 & 0.29 & 994.3 & 1003.86 & 0.028 & 0.95 \\
\hline UMOIO & 9.04 & 0.89 & 8.15 & 0.23 & 995.18 & 1003.33 & 0.022 & 0.81 \\
\hline UMOII & 5.45 & 0.28 & 5.18 & 0.1 & 997.14 & 1002.32 & 0.01 & 0.52 \\
\hline UMOI2 & 14.72 & 0.58 & 14.14 & 0.25 & 991.77 & 1005.91 & 0.025 & $1.4 \mid$ \\
\hline UMOI3 & 15.87 & 2.48 & 13.39 & 0.21 & 995.5 & 1008.89 & 0.021 & 1.33 \\
\hline
\end{tabular}
to equations (1) and (3) are provided in Table 3.

Table 3 Integral intensities of signals in 'H NMR spectra of the samples analyzed and $\mathrm{H}_{\text {bay }}$ and $\mathrm{H}_{\text {arom }}$ content as determined according to equations ( $\mathrm{I}$ ) and (2). 
Table Continued....

\begin{tabular}{|c|c|c|c|c|c|c|c|c|}
\hline \multirow[t]{3}{*}{ Sample } & \multirow[t]{2}{*}{$I_{0}$} & \multirow[t]{2}{*}{$I_{\mathrm{CHCl3}}$} & $I_{\text {arom }}$ & \multirow[t]{2}{*}{$I_{\text {Hbay }}$} & \multirow[t]{2}{*}{$I_{\text {alif }}$} & \multirow[t]{2}{*}{$I_{\text {total }}$} & \multirow[t]{2}{*}{$\% \mathbf{H}_{\text {bay }}$} & \multirow[t]{3}{*}{$\% \mathbf{H}_{\text {arom }}$} \\
\hline & & & $=I_{0}-I_{\mathrm{CHCl} 3}$ & & & & & \\
\hline & 9.5-6.0 ppm & 7.23 ppm & 9.5-6.0 ppm & 9.5-8.3 ppm & 5.8-0.2 ppm & \multicolumn{2}{|c|}{ 9.5-0.2 ppm } & \\
\hline UMOI6 & 8.53 & 0.61 & 7.92 & 0.26 & 995.22 & 1003.14 & 0.025 & 0.79 \\
\hline UMOI7 & 9.86 & 1.25 & 8.61 & 0.26 & 1000 & $1008.6 \mid$ & 0.026 & 0.85 \\
\hline UMOI8 & 12.03 & 1.22 & 10.81 & 0.27 & 1000 & 1010.81 & 0.027 & 1.07 \\
\hline UMOI9 & 10.07 & 1.23 & 8.84 & 0.19 & 996.45 & 1005.29 & 0.019 & 0.88 \\
\hline UMO20 & 11.98 & 0.69 & 11.3 & 0.34 & 993.54 & 1004.84 & 0.034 & 1.12 \\
\hline UMO2I & 9.51 & 0.75 & 8.76 & 0.24 & 995.27 & 1004.03 & 0.023 & 0.87 \\
\hline UMO22 & 10.76 & 0.56 & 10.2 & 0.31 & 994.23 & 1004.43 & 0.031 & 1.02 \\
\hline UMO23 & 7.46 & 0.44 & 7.02 & 0.24 & 995.72 & 1002.73 & 0.023 & 0.7 \\
\hline UMO24 & 8.25 & 0.6 & 7.65 & 0.19 & 1000 & 1007.65 & 0.019 & 0.76 \\
\hline UMO25 & 8.36 & 0.96 & 7.4 & 0.25 & 1000 & 1007.4 & 0.025 & 0.73 \\
\hline UMO26 & 7.39 & 0.9 & 6.49 & 0.31 & 1000 & 1006.49 & 0.031 & 0.64 \\
\hline UMO27 & 7.36 & 0.6 & 6.49 & 0.23 & 1000 & 1006.49 & 0.031 & 0.64 \\
\hline UMO28 & $|1.5|$ & 1.13 & 10.38 & 0.16 & 1000 & 1010.38 & 0.016 & 1.03 \\
\hline UMO29 & 5.37 & 0.91 & 4.47 & 0.16 & 1000 & 1004.47 & 0.015 & 0.44 \\
\hline UMO30 & 8.96 & 0.6 & 4.47 & 0.2 & 1000 & 1004.47 & 0.015 & 0.44 \\
\hline UMO3I & 3.02 & 0.45 & 2.57 & 0.08 & 1000 & 1004.47 & 0.008 & 0.26 \\
\hline UMO32 & 3.31 & 0.54 & 2.77 & 0.06 & 1000 & 1002.77 & 0.006 & 0.27 \\
\hline
\end{tabular}

According to the ISO document, ${ }^{39}$ the criterion for the determination of the nature of oil as a raw material for use in the rubber industry is defined as:
i. \% Hbay $\leq 0.35 \%$ oil is non-polyaromatic,
ii. \% Hbay $\geq 0.35 \%$ oil is polyaromatic.

According to Table 3, the PAH content, expressed as \% Hbay, was very low in all the samples: $\%$ Hbay $\leq 0.05 \%$, i.e. at least 7 times lower than the stipulated limit. This unambiguously demonstrates that the UMO tested are not toxic in terms of PAH content. This fact is also indicated in Figure 3 containing a graphic comparison of Hbay hydrogen content in the samples analyzed by NMR spectroscopy, with the limit set applicable to oil nature determination Figure 3.

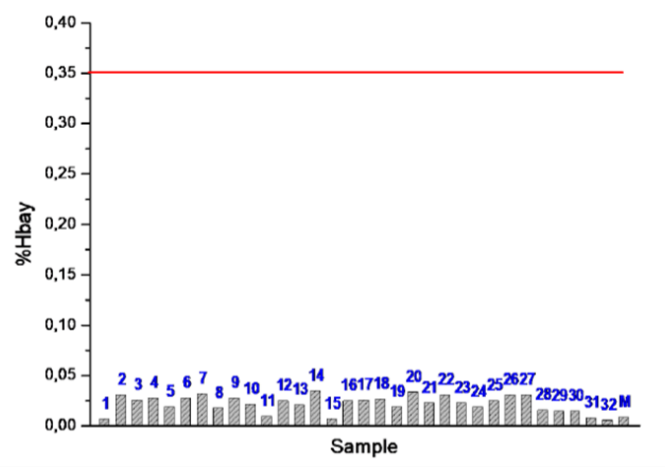

Figure 3 Graphic comparison of Hbay hydrogen content in the samples analyzed by NMR spectroscopy with the limit used for oil nature determination.
The Hbay proportion in the reference sample of the fresh motor oil MADIT is very low as expected. A low Hbay content in both UMO test samples from cogeneration plants (samples No. UMO31 and UMO32) is apparently related to the specific mode of engine operation in such facilities. After the start-up and stabilization of parameters, an optimally tuned engine keeps running for tens to hundreds of hours with no fluctuations and disturbances. Half of the samples (15 samples) were evaluated using both procedures-by the modified method IP 346 involving the determination of $\sum 8 \mathrm{PAH}$ content (see Table 2) and the Hbay method (Table 3). The pairs of the data thus obtained can be used for correlation between $\Sigma 8 \mathrm{PAH}$ and Hbay. A graphic representation of this relationship is provided in Figure 4 . There is a relatively good correlation between both methods used. The NMR analysis results may only be compared with the sum of the contents of all PAH determined by the IP 346 method. This is because in a NMR spectrum all components of a sample are manifested simultaneously. A low correlation coefficient is associated with low Hbay content and so with a great standard deviation of NMR measurements Figure 4.

\section{Heavy metals in UMO}

About 1.7 and 3.5 million tons of UMO is collected in the EU and US each year, respectively. ${ }^{40}$ In the US, approximately $83 \%$ of this amount is burned and $17 \%$ re-refined, while in the EU these figures are 77 and 33\%, respectively. At present, burning as fuel and re-refining and distillation are three main methods for UMO recyclation. In view of the presence of hazardous heavy metals UMO is not considered hazardous waste if they are not exceeded regulatory limits in force, for example, in the United States. Regulatory limits for hazardous 
heavy metals are as follows (in mg/kg UMO): 5 for As, 2 for $\mathrm{Cd}, 10$ for $\mathrm{Cr}, 100$ for $\mathrm{Pb}$, for sulphur - variable, usually $1 \%, 4000$ for total halogens and flash point not lower than $45^{\circ} \mathrm{C} .{ }^{41}$ Such UMO can be burned in conventional boilers. If UMO exceeds permissible levels its energy utilization is restricted to industrial burners and utility boilers, industrial furnaces and hazard waste incinerators that meat specified provisions Table 4.

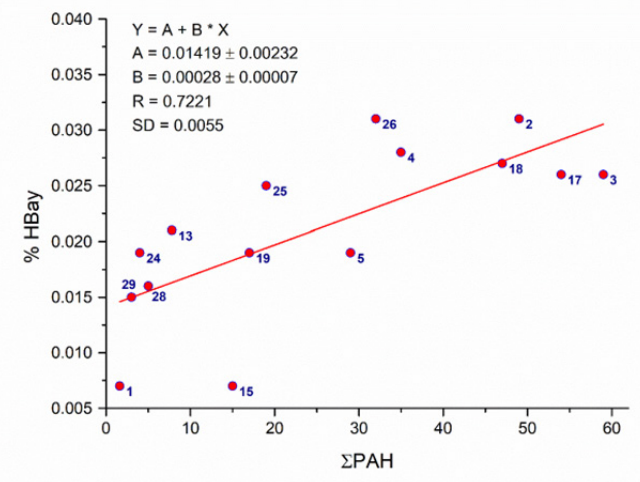

Figure 4 Graphic comparison of the results of $\Sigma 8 \mathrm{PAH}$ content determination by IP 346 and NMR method. R is the correlation coefficient and SD is its standard deviation.

In Table 4 are given some parameters of our UMO samples tested in terms of heavy metals. The comparison with the permissible values $^{1}$ indicates that the levels of heavy metals observed in the three samples tested UMO are order of magnitude lower than the limit data. Therefore, samples can be considered as a standard waste and energetically utilized in simple combustion plants. Thus, not only in terms of the content of PAHs, but also in terms of the content of hazardous heavy metals the improved quality of current UMO is confirmed, although evaluated set of UMO samples is small and further testing in this respect is required. Surprisingly high is the flash point, which is observed in all three samples. The content of heavy metals in the UMO shows permanent downward trend for the last decades. ${ }^{1}$ The lead concentrations determined in UMO samples collected in 2009 were much lower ( 33 to $55 \mathrm{mg} / \mathrm{kg}$ ) than that reported in the $1980 \mathrm{~s}(555 \mathrm{mg} / \mathrm{kg}){ }^{1}$

Table 4 UMO properties and hazardous constituent content in tested UMO samples.

\begin{tabular}{llll}
\hline $\begin{array}{llll}\text { Property/Constituent, mg/kg } \\
\text { UMO }\end{array}$ & UMO 4 & UMO I3 & UMO I5 \\
\hline Arsenic & $<0.5$ & $<0.5$ & $<0.5$ \\
Cadmium & $<0.05$ & $<0.05$ & $<0.05$ \\
Chromium & $<0.05$ & 0.24 & $<0.05$ \\
Lead & 1.8 & 10.9 & 0.84 \\
Sulphur, \% wt. & 0.48 & 0.48 & 0.5 \\
Polychlorinated biphenyls & n.a. & n.a. & n.a. \\
Total organic halogen as chlorine & n.a. & n.a. & n.a. \\
Flash point ${ }^{\circ} \mathrm{C}$ & $\mathrm{I} 68$ & 156 & 213 \\
\hline
\end{tabular}

n.a. - not analysed

Based on the results obtained, it can be expected that at present all separate collection in servicing and garages, equipped with modern suction technique, will show the contents of the reference benzo(a) pyrene far below the limit value of $0.005 \%$ and will be able to be used immediately for energy even in simpler combustion plants after resolution of emissions and ash. Such UMO could possibly be used at the place of their obtaining (i.e. car repair shop, garage etc.) for energy utilization purposes, such as heating of service water, heating of premises etc. In the case of exceeding regulatory limits, a prerequisite for such a use is ecologically acceptable incineration in incinerators fitted with a gas-cleaning system and treatment of ash in an environmentally protective manner.

The economic impact of utilization of UMO as an energy source in such facilities would be particularly favorable. The price of UMO per energy unit is lower than the price of common fuels-light fuel oil or natural gas. Thus a potential opportunity would be gained to dispose of the originally hazardous waste in an intriguing and economically beneficial way. It would also mean diversification of energy sources of domestic origin. Furthermore, administrative burden associated with hazardous waste treatment would be eliminated, too. When UMO is utilized for energy purposes, there is no need for their storage and transport over large distances, which involves a potential risk of environmental pollution. It is necessary indeed to realize that it will not be easy to amend and moderate existing measures and laws related to UMO disposal. We regard it necessary to draw the attention of experts in this fact and pay more attention to this problem. However, the current legislation applicable to UMO was adopted basically decades ago under technological circumstances much different from those prevailing at present.

${ }^{1} \mathrm{H}$ NMR spectroscopy proved useful in assessing PAH content in UMO samples. NMR analysis is based on the ability of NMR to discern and quantify NMR-active nuclei bound in various structural fragments of molecules. An advantage of NMR lies in the fact that NMR measurements can be carried out in such a way that the sensitivity of determining various fragment types is identical, which allows obtaining undistorted data on the content of individual structural types even without using standards. Another advantage is a simple preparation of the sample without it having to be separated and specially treated, which also increases the method's reliability. NMR is an absolute method by its nature, requiring for sample analysis no calibration or comparison with spectra of the standards or with any database data.

\section{Conclusion}

The aim of our study was to highlight and acknowledge the possibility of the simplest energetic UMO utilization by its combustion without restrictions and limits, preferably at the place of its collection. Experimental results obtained in the study show that the content of benzo(a)pyrene monitored in the representative set of all $32 \mathrm{UMO}$ samples is well below the admissible limit of $0.005 \%(50 \mathrm{mg} / \mathrm{kg})$, which makes it possible for UMO not to be classified as hazardous waste.

The NMR analysis of the UMO samples tested clearly demonstrated that all samples contained very small PAH amounts and this content was at least 7 times lower than the limit value. The comparison of the NMR analysis results with the results obtained by a modified IP 346 method implies that there is a significant correlation between the results.

\section{Acknowledgements}

Financial support from the Recycle Fund of Slovakia (Recyklačný fond Slovensko), Project No. 1182/14/02, is gratefully acknowledged. 


\section{Conflict of interest}

The author declares no conflict of interest.

\section{References}

1. Pawlak Z, Urbaniak W, Kaldonski T, et al. Energy conversation through recycling of used oil. Ecol Eng. 2010;36:1761-1764.

2. Pasquini R, Monarca S. Detection of mutagenic/carcinogenic compounds in unused and used motor oils. Sci Total Environ. 1983;32(1):55-64.

3. Vazquez-Duhalt R. Environmental impact of used motor oil. Sci Total Environ. 1989;79(1):1-23.

4. Grimmer G, Jacob J, Naujack KW. Profile of the polycyclic aromatic hydrocarbons from lubricating oils:Part 1 . Inventory by GC/MS-PAH in environmental materials. Fresenius Z Anal Chem. 1981;306(5):347-355.

5. Brown JM, Wise SA, May WE. Determination benzo(a)pyrene in recycled oils by a sequential HPLC method. J Environ Sci Health. 1980;15(6):613-623.

6. Durand JP, Petroff N. Determination of benzo(a)pyrene and other polyaromatic hydrocarbons in petroleum oils by direct liquid chromatography. J Chrom. 1980;190:85-95.

7. Hoffman DJ, Eastin WC, Gay ML. Embryotoxic and biochemical effects of waste crankcase oil on birds eggs. Toxicol Appl Pharmacol. 1982;63(2):230-241.

8. Grimmer G, Jacob J, Naujack KW, et al. Profile of the polycyclic aromatic hydrocarbons from used engine oils:Part 1. Inventory by GC/MS-PAH in environmental materials. Fresenius Z Anal Chem. 1981;309(1):13-19.

9. Grimmer G, Naujack KW, Dettbarn G, et al. Studies on the cancerogenic action of used engine lubricating motor oil. Erdoel Kohle Erdgas Petrochem. 1982;35:466-472.

10. Harvey RG. Polycyclic Hydrocarbons and Cancer. Am Scientist. 1982;70:386-393.

11. Payne JF, Martins I, Rahimtula A. Crankcase oils: are they a major mutagenic burden in the aquatic environment? Science. 1978;200(4339):329-330.

12. Peake E, Parker K. Polynuclear aromatic hydrocarbons and the mutagenicity of used crankcase oils. In: Bjorseth A, et al. editors, Polynuclear aromatic hydrocarbons: Chemical and biological effects. Columbus: Battelle Press; 1980. p. 1025-1039.

13. Lu ST, Kaplan IR. Characterization of motor lubricating oils and their oil-water partition. Environ Forensics. 2008;9(4):295-309.

14. Pruell RJ, Quinn JG. Accumulation of polycyclic aromatic hydrocarbons in crankcase oil. Environ Poll. 1988;49:89-97.

15. Srogi K. Monitoring of environmental exposure to polycyclic aromatic hydrocarbons: a review. Environ Chem Lett. 2007;5(4):169-195.

16. Clonfero E, Nardini B, Marchioro M, et al. Mutagenicity and contents of polycyclic aromatic hydrocarbons in used and recycled motor oils. Mutat Res. 1996;368(3-4):283-291.

17. Van Donkelaar P. Environmental effects of crankcase- and mixedlubrication. Sci Total Environ. 1990;92:165-179.

18. Hewstone RK. Health, safety and environmental aspects of used crankcase lubricating oils. SciTotal Environ. 1994;156(3):255-268.

19. Regulation (EC) 1907/2006 - REACH.

20. UK Institute of Petroleum Standard Methods for Analysis and Testing of Petroleum and related Products. Method IP 346/1996: Determination of polycyclic aromatics in unused lubricating base oils and asphaltene free petroleum fractions - Dimethyl sulphoxide extraction refractive index method. 1996
21. Gilgenast E, Boczkaj G, Przyjazny A, et al. Sample preparation procedure for the determination of PAH in petroleum vacuuam residue and bitume. Anal Bioanal Chem. 2011;401(3):1059-1069.

22. Mackerer CR, Griffis LC, Grabowski JS, et al. Petroleum Mineral Oil Refining and Evaluation of Cancer Hazard. Appl Occup Environ Hyg. 2003;18(11):890-901.

23. Kuo CY, Cheng YW, Chen YW, et al. Correlation between the amounts of polycyclic aromatic hydrocarbons and mutagenicity of airborne particulate samples from Taichung City, Taiwan. Environ Res Sec A. 1998;78(1):43-49.

24. Wang XL, Tao S, Dawson RW, et al. Characterizing and comparing risks of polycyclic aromatic hydrocarbons in a Tianjin wastewater-irrigated area. Environ Res. 2002;90(3):201-206.

25. Srogi K. Monitoring of environmental exposure to polycyclic aromatic hydrocarbons: a review. Environ Chem Let. 2007;5:169-195.

26. Ames BN, McCann J, Yamasaki E. Methods for detecting carcinogens and mutagens with the Salmonella/mammalian microsome mutagenicity test. Mutat Res. 1975;31(6):347-364.

27. Purchase IFH. An appraisal of predictive tests for carcinogenicity. Mutat Res. 1982;99:53-71.

28. Coker DT, King AG, Mumford DL, et al. Carcinogenic Assessment of Petroleum Products by Nuclear Magnetic Resonance. Anal Commun. 1997;34(5):137-140.

29. Di Serio M, Vitiello R, Del Litto R, et al. Assessment of the Carcinogenicity of Lubricant Base Oils Using a Non-Conventional Analytical Method. $17^{\text {th }}$ International colloquium tribology 2010 Solving friction and wear problems. 2010;2:1638-1640.

30. Cvengroš J. Regeneration of used mineral oils. Erdoel Erdgas Kohle. 2000;116:127-128.

31. Waste Incineration Directive 2000/76/EC.

32. Vorapot Kanokkantapong, Worapon Kiatkittippong, Bunyarit Panyapinyopol, et al. Used lubricating oil management options based on life cycle thinking. Res Conserv Rec. 2009;53(5):294-299.

33. Delistraty D, Stone A. Dioxins, metals and fish toxicity in ash residue from space heaters burning used motor oil. Chemosphere. 2007;68:907914.

34. Determination of PAH Emmisions from Stationary Sources. US EPA 429/1997, ISO EN 11338.

35. www.atsdr.cdc.gov/csem/pah/docs/pah.pdf

36. Jerina DM, Lehr RE, Yagi. Mutagenicity of $b(a) p$ derivatives and the description of a quantum mechanical model which predicts the ease of carbonium ion formation from diol epoxides. In: deSerres FJ, et al. editors, In vitro metabolic activation in mutagenesis testing. Amsterdam, The Netherlands. 1976. p.159-178.

37. Jerina DM, Sayer JM, Thakker DR. Carcinogenicity of polycylic aromatic hydrocarbons: The bay-region theory. In: Pullman B, et al. editors. Carcinogenesis: Fundamental mechanisms and environmental effects. Hingham, Reidel Publishing Co. 1980. p. 1-12.

38. Weis LM. Bay or baylike regions of polycyclic aromatic hydrocarbons were potent inhibitors of gap junctional intercellular communication. Environ Health Perspect. 1998;106(1):17-22.

39. Rubber. Determination of aromaticity of oil by NMR spectroscopy. ISO document: ISO/TC 45/SC 3 N, 2011-05-16. 2011.

40. Boughton B, Horvath A. Environmental assessment of used oil management methods. Environ Sci Technol. 2004;38(2):353-358.

41. Rauckyte T, DJ Hargreaves, Pawlak Z. Determination of heavy metals and volatile aromatic compounds in used engine oils and sludges. Fuel. 2006;85:481-485. 